\title{
East-Asian Students' Choice of Canadian Graduate Schools
}

Received (in revised form): October 6, 2007

\section{Liang-Hsuan Chen}

is a lecturer in Accounting in the Department of Management at the University of Toronto at Scarborough and an associate faculty member at the Ontario Institute for Studies in Education of the University of Toronto (OISE/UT). Her research interests include college choice, graduate education, international education, professional education, teaching, learning, and the student experience. Liang is an elected member of the Board of Governors of the Certified General Accountants of Ontario. She holds an MSEd from the University of Pennsylvania, an MBA from the University of Toronto, and a Ph.D. in Higher Education from OISE/UT.

\section{Abstract}

This study seeks to explain why and how international graduate students from East Asia choose to come to Canada to pursue advanced education, to assess the strengths and dynamics of the factors influencing the enrollment decision, and to describe possible implications both for educationexporting countries and universities offering graduate education. A synthesis model is developed to explain their decision-making process, while a push-pull model is used to understand the strengths of and relationships among various factors that influence the choice of a country, institution, program, and city. The research sample comprised 140 students from China, Hong Kong, Japan, Korea, and Taiwan who enrolled in graduate



programs at two large Ontario universities. The research shows a three-stage process, guided first by the focus of the program (i.e. researchoriented versus professional programs). Other factors-country, institution, and city-interplay simultaneously at the later two stages. The research findings reveal the significant influence of academic (Academic Pulling Factors and Administrative Pulling Factors), economic, environmental, and visa/ immigration pulling factors as well as a set of negative pushing factors from third countries such as the United States. This research suggests that to attract top international graduate students, policy makers and institutional administrators should focus on investing in research and ensuring the quality of graduate education, while devoting efforts and resources to the internationalization of graduate education, as well as crafting a national marketing strategy to enhance awareness of and the overall image of their higher education institutions and programs. International Journal of Educational Advancement (2007) 7, 271-306. doi:10.1057/palgrave.ijea.2150071 
Keywords:

international education, enrollment management, college choice

\section{Introduction}

Interest in international students has been a phenomenon in recent decades mainly for academic, economic, political, and cultural reasons. ${ }^{1}$ International study and the international flow of students, however, can be traced back to ancient times, as early as $600 \mathrm{BC}$ in India (Altekar, 1965), and in other civilizations such as China, Persia, Greece, Rome, and Western Europe (Dedijer, 1968; Hess, 1982). These civilizations enrolled students from many countries, and used international languages, such as Sanskrit, Pali, Greek, or Latin, as instructional languages. In the medieval European universities, such as Bologna, Cordova, Florence, Louvain, Paris, and Salerno, the faculty was generally international in nature, and "foreign students were the norm not the exception" (Altbach and Lulat, 1985, p. 441). Universities and other higher educational institutions have been international institutions throughout their history. Indeed, "international education has constituted one of the most important elements in institutions of higher education in all countries and all times" (Hess, 1982, p. 1), and so the internationalization of higher education is not a recent phenomenon.

International graduate students are a very special group of people, belonging to the so-called "creative class" (Florida, 2002), who travel from afar to pursue advanced education both for the love of knowledge and for personal and professional advancement. They play an important role in Canadian graduate education by bringing academic, cultural, and economic benefits to our learning environment and society; subsequently, they are ambassadors of Canadian education to the world.

Canada's future sustainability and growth will depend on new immigrants who are educated skilled workers. The international student population has been viewed by many as a pool of preferred potential immigrants. The 2002 Speech from the Throne The Canada We Want outlined the need for Canada to be a magnet for talent and investment. In particular, the government will "position Canada as a destination of choice for talented foreign students and skilled workers by more aggressively selecting and recruiting through universities and in key embassies abroad" (Government of Canada, 2002, p. 9). It is clear that Canada, including all levels of government and institution, has a great interest in international students. Despite the importance of their presence in our learning environment and society, existing research on international graduate students, especially in the Canadian context, is minimal.

This is the first research focusing on this group of international students and their choice of a Canadian graduate school. The three purposes of this study are (1) to understand the process of deciding to undertake overseas graduate studies, and thus to develop a framework to explain the factors influencing international students' choice of a Canadian graduate school, (2) to assess the strengths and dynamics of the factors influencing the enrollment decision, and (3) to discuss possible implications 
both for education-exporting countries and for universities offering graduate education.

\section{Theoretical Framework}

The existing college choice literature gives little consideration to the unique characteristics of international graduate students. Typically, the literature groups them with other graduate students or with undergraduate international students. Therefore, there was a need to develop a more comprehensive and dynamic model to explain international graduate students' choice and decisionmaking process, building on existing "conceptual" frameworks of college choice models and theories on factors or variables influencing students' choice of undergraduate and/or graduate programs. An extensive review of previous studies was conducted to build the Synthesis Model for this study. Three domains of literature were reviewed-covering undergraduate students, graduate students, and international students-as well as studies on college choice factors, such as location characteristics, economics of international graduate education, visa, and education/immigration/mobility. The push-pull model was also reviewed to understand the strengths of and relationships among various factors that influence the choice of a country, institution, program, and city. The literature on internationalization and marketing helped to guide the study regarding this particular group of students' overseas studies decisionmaking process.

\section{The Synthesis Model}

The Synthesis Model is a comprehensive and dynamic model that incorporates the process models and important factors. Its process is based on Hossler and Gallagher's model (1987) and Neice and Braun's (1977) three-phase model, and Mazzarol and Soutar's (2002b) “pushpull" model. Its concept is rooted in econometric models, marketing models, and information-processing models. It also borrows the fundamentals from the sociological models and social capital theory at an early stage, and then moves on to Florida's "creative capital" theory (2002). Figure 1 shows the concept, process, and factors of the model.

There are three stages in the process of choosing overseas study-the decision to study abroad, the choice of a host country, and the selection of a host institution. In most situations, students first decide to study abroad rather than study locally; they then choose a host country, and finally, a host institution. In other situations, students by-pass the process of choosing a host country, and choose a host institution directly. At each stage, the decisions are influenced by three domains of factors-Student Characteristics, Significant Others, and External Push-Pull Factors. Student characteristics include socioeconomic background, personal characteristics and preferences, academic ability, social capital, and creative capital. Significant others include encouragement from family/ spouse, relatives, professors, sponsors, or employers. External influencespush and pull factors-include positive and negative forces from the home and host countries, personal driving forces due to external influences, and institutional characteristics. By the end of the search stage for institutions, students will derive a choice set of 


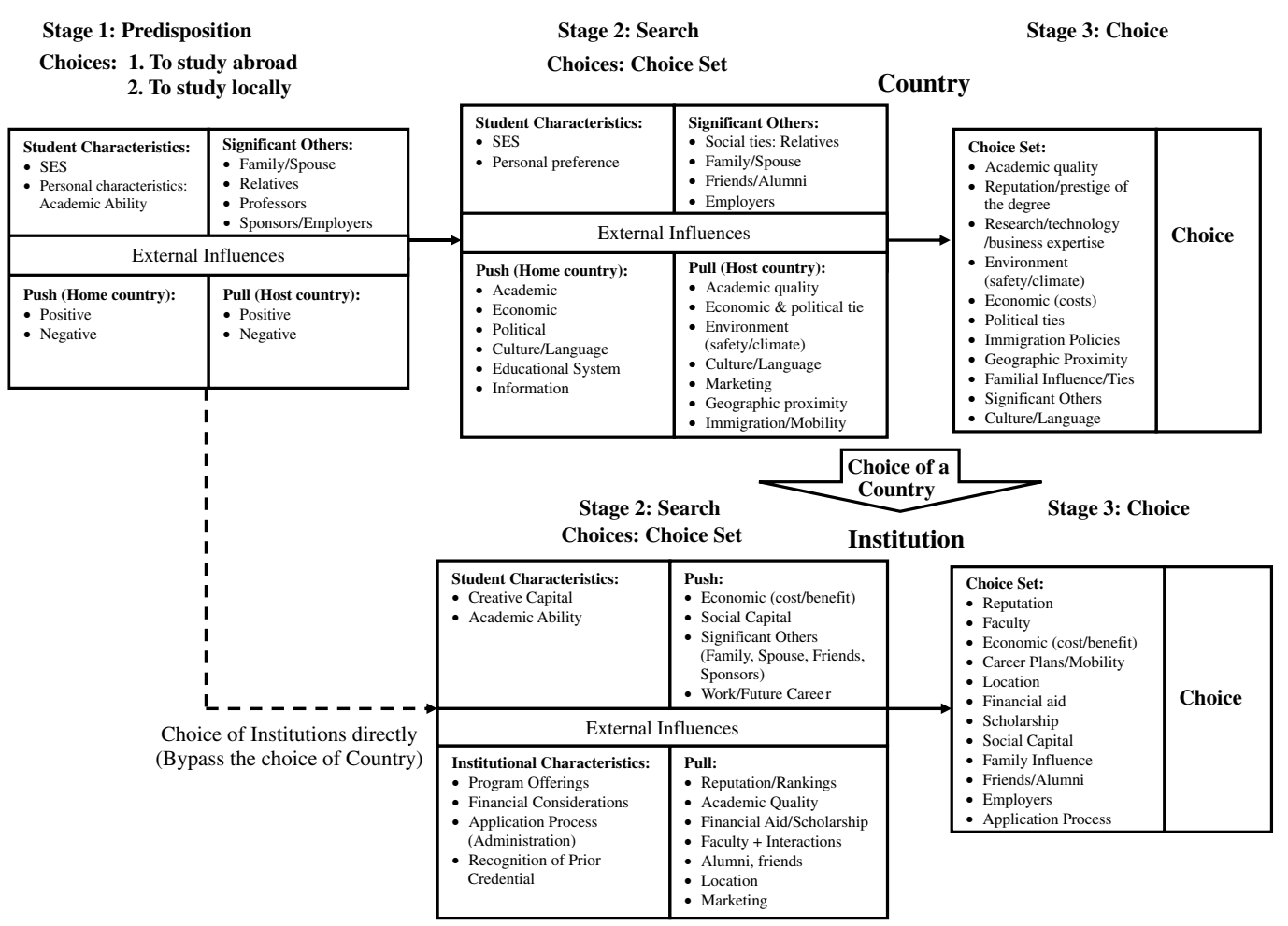

Figure 1: The (Original) Synthesis Model

institutions from which to make applications. The final stage of the school choice is to select one school from the set of offers of admission. Students will make trade-offs among the factors considered in the search stage, and reach a final choice.

\section{The Push-Pull Model}

A push-pull model was originally used in the theory of migration (E. S. Lee, 1966) to explain the factors influencing the movement of people. The model has been used to understand international student flows (Neice and Braun, 1977; Cummings, 1984; K.H. Lee and Tan, 1984; Sirowy and Inkeles, 1984; Agarwal and Winkler, 1985; Cummings and So, 1985), the decision or motivation to study abroad (Glaser, 1978; Rao, 1979; Altbach and Lulat, 1985), and the international students' choice of a country (Mazzarol and Soutar, 2002b). The push factors are the factors associated with the home country. Some push factors are positive and some are negative in nature, while pull factors are in general positive to attract international students to the destination. In essence, the decision, motivations, and flow of international students are "a function of the combined 'pull' factors and 'push' factors as influenced by intervening obstacles" (Sirowy and Inkeles, 1984, p. 65). Neice and Braun (1977) explained that the push factors had strength in the initial reasons for 
studying abroad, while the pull factors dominated the choices, especially the appeal of program availability.

The push-pull model has been primarily used to explain international students' decision-making process in the first two stages, which are (1) the "predisposition" or motivation stagethe decision to study abroad, and (2) the "search" or information gathering stage-the choice of a country. This study takes this model one step further, to the last stage of the decision-making process-the "choice" of an institution, because it touches on the academic, economic, environmental, and informational factors that are closely tied to other college choice models.

\section{Internationalization and Marketing} According to De Wit (2002), there are four approaches to internationalization, namely, activity, rationale, competency, and process. The two most-used approaches to defining internationalization, which also have a direct impact on international students, are the activity approach described as a series of activities, programs, and services (Harari, 1977, 1989; Arum and Van de Water, 1992), research, scholarly, and international organization collaboration (Beerkens and Derwende, 2007), export of knowledge and education (Harman, 2002; Mazzarol and Soutar, 2002a), and the process approach that involves policies (Callan, 1998; Enders, 2004) and moves the higher educational institutions in an international direction (Schoorman, 1999; Harman, 2005). Harari defined internationalization as "the international content of the curricula, the international movement of scholars and students concerned with training and research, and the arrangements that engage a system of education cooperation programs beyond its national boundaries" (1977, p. 2293), while Knight sees internationalization as "the process of integrating an international/intercultural dimension into the teaching, research and service functions of the institution" (1999, p. 16).

In applying marketing concepts to education, Kotler and Fox defined marketing as "the analysis, planning, implementation, and control of carefully formulated programs designed to bring about voluntary exchanges of values with target markets, to achieve institutional objectives. Marketing involves designing the institution's offerings to meet the target market's needs and desires, and using effective pricing, communication, and distribution to inform, motivate, and service the markets" (1985, p. 7). Various studies (College Entrance Examination Board, 1976; Krampf and Heinlein, 1981; Brooker and Noble, 1985) used the marketing model, which applies marketing principles, such as marketing mix, segmentation, positioning, and marketing research, to study student choice and to address decreasing enrollments. Much of the research in marketing education to international students is carried out in Australia and the United Kingdom. The focus is on strategic marketing, differentiation, and competitiveness (Mazzarol and Hosie, 1996; Mazzarol and Soutar, 2002a; Binsardi and Ekwulugo, 2003; Hemsley-Brown and Oplatka, 2006) at the institutional and national level.

Most of the studies in international students' choice neglected to assess the impact of the internationalization 
process and activities and marketing efforts on the international students' choice of a host country and a host institution. This study examined their roles as factors influencing international students' choice and their respective outcomes in attracting and recruiting international students.

\section{Methodology}

This study used a combination of quantitative and qualitative research methods to explain the factors and process. Quantitative data from a mailed survey questionnaire were used to identify the factors and to measure their significance in influencing or determining the choice of overseas graduate schools. Qualitative data from in-person interviews were used to gain insights into how international graduate students decide to pursue international studies and select a country, institution, program, and location. Triangulation was used in this research to determine the consistency of data collected from both methods, and the research findings were compared to the findings from the literature review.

The survey items were developed based on a review of previous questionnaires (Neice and Braun, 1977; Zikopoulos and Barber, 1986; Austin, 1988; Gagnon andCocolas, 1988; Olson, 1992; Webb, 1993; Poock and Love, 2001), and these items were grouped into three domains of factorsStudent Characteristics, Significant Others, and External Push-Pull factors. The survey questionnaire followed the three-stage temporal flow of the synthesis model and the study-abroad decision-choice of country, choice of institution/program, and future plans.
The research subjects comprised international graduate students from China, Hong Kong, Japan, Korea, and Taiwan who enrolled in two large universities in the city of Toronto-the University of Toronto and York University-in the academic year of 2003-04. These East Asian jurisdictions were chosen because of their importance as a source of graduate students across North America. International students from these jurisdictions represented almost one-fifth of the graduate-level international enrollment in Canada for the three academic years 1997-2000 (Bartlett and Kane, 2002), and international graduate students from these jurisdictions represented 41 percent of the total international graduate student enrollment in the United States (Davis, 2000). Prior to 1994, Hong Kong and Japan were leading countries sending students to Canada; however, after 1994, Korea and China became the leading countries sending students to Canada (Citizenship and Immigration Canada, 2003). Although Hong Kong is now part of China, its history of being part of the Commonwealth had a significant impact on the pattern of sending students to Canada compared with the Chinese experience, and so the data were collected and analyzed separately.

Ontario hosted the largest number of international students at all levels combined (Citizenship and Immigration Canada, 2006). The University of Toronto and York University were chosen for the study because they are among the largest Ontario universities hosting a very high number of international students, especially at the graduate level in 2003 
(Canadian Association for Graduate Studies, 2005). The city of Toronto was chosen mainly to test the causal relationship between the location and enrollment decision: among the 43 North American metropolitan regions with populations over one million, the city of Toronto has been ranked number one in diversity and number four in creativity (Gertler et al., 2002).

Paper-based survey questionnaires were mailed directly from the two universities to a total population of 450 international graduate students, and 140 surveys (31 percent) were returned. The recruitment of the interview participants was via selfselection, as interview participants were asked in the questionnaire whether they would be interested in participating in an in-depth interview, and 23 graduate students participated in in-depth interviews. The in-depth interviews were semi-structured, and the interview format consisted of small group discussions, individual interviews, and online interviews.

Besides the country of origin, there was no additional information available on the population regarding gender, age, level of study, and the field of study. The respondents mirrored the total population in terms of country of origin. Students from China represented 67 percent of the total respondents, Hong Kong 4 percent, Japan 13 percent, Korea 11 percent, and Taiwan 4 percent. Half of the respondents were enrolled at the doctoral level and the rest at the Master's level (refer to Table 1). Thirty-two percent of the respondents were between 21 and 25 years of age, 47 percent were between 26 and 30 , and 21 percent were over 30 years of age. Twenty-two percent of the respondents were enrolled in arts and humanities, 27 percent in business, 7 percent in education, 34 percent in engineering and science, 2 percent in law, and 6 percent in medical and health. The demographic data and the field of study of the interviewees mirrored the survey respondents.

\section{Findings from the Survey- Study-Abroad Decision, Choice of Canada, and an Institution}

The data analyzed and presented below were based on five sets of independent variables, which showed the most significant difference between and among the groups: (1) country of origin, (2) attitude/preference

Table 1: The composition and background of the survey respondents

\begin{tabular}{|c|c|c|c|c|c|c|c|c|c|}
\hline \multirow[b]{2}{*}{$\begin{array}{l}\text { Country of } \\
\text { citizenship }\end{array}$} & \multicolumn{2}{|c|}{ Gender } & \multicolumn{2}{|l|}{ University } & \multicolumn{3}{|c|}{ Types of programs } & \multirow[b]{2}{*}{ Total } & \multirow[b]{2}{*}{$\%$} \\
\hline & Male & Female & U Toronto & York U & $\begin{array}{l}\text { Doctoral } \\
\text { research }\end{array}$ & $\begin{array}{l}\text { Master } \\
\text { research }\end{array}$ & $\begin{array}{l}\text { Master } \\
\text { professional }\end{array}$ & & \\
\hline China & 44 & 45 & 63 & 26 & 48 & 18 & 23 & 89 & 64 \\
\hline Hong Kong & 2 & 4 & 4 & 2 & 4 & 1 & 1 & 6 & 4 \\
\hline Japan & 9 & 16 & 16 & 9 & 10 & 8 & 7 & 25 & 18 \\
\hline Korea & 7 & 3 & 3 & 7 & 4 & 2 & 4 & 10 & 7 \\
\hline Taiwan & 6 & 4 & 5 & 5 & 4 & 1 & 5 & 10 & 7 \\
\hline Total & 68 & 72 & 91 & 49 & 70 & 30 & 40 & 140 & 100 \\
\hline
\end{tabular}


(i.e. whether Canada was the country of first choice), (3) types of program enrolled (i.e. research programs versus professional programs), (4) fields of study, and (5) university enrolled. There were 100 students in research programs (including 70 students at the doctoral level and 30 at the master's level), and 40 in professional programs. Students enrolled in research programs included both doctoral and selected master students, and most of them received funding. Professional students were mainly self-funded, and their degree programs included Business and Management (22), Education (3), and Engineering (11).

\section{Applications pattern and preference/attitude}

The vast majority (92 percent) of the respondents reported that their program of study was their first choice, and 81 percent of the respondents reported that their university was their first choice in Canada. Two-thirds of those who reported that their university was not their first choice identified American universities as their first choice. Seventy-one respondents (51 percent) reported that Canada was their first choice, while 67 respondents (49 percent) reported that Canada was not their first choice.

After a closer examination, it was evident that there were significant differences based on the country of origin, and between genders. The majority of Japanese, Hong Kong, and Korean students reported that Canada was their first-choice country, while half of the Taiwanese students reported that Canada was their first-choice country. More than half (63 percent) of the Chinese students reported that Canada was not their first-choice country. More female than male students had a preference toward Canada as their first-choice country (refer to Table 2).

Almost all (65 respondents or 98 percent) of those respondents reporting that Canada was not their first choice of country identified the United States as their first choice of country.

Although 71 respondents reported that Canada was their first-choice country, 89 (64 percent) respondents had applied to universities outside Canada. The United States was the country most respondents (70) identified as the country they applied to. Fourteen respondents reported that they had applied to schools in the United States and in another country. It was evident that outside of Canada, the United

Table 2: Cross-tabulation of Canada was my first-choice country and country of origin

\begin{tabular}{|c|c|c|c|c|c|c|c|c|c|c|c|c|}
\hline \multirow{3}{*}{$\begin{array}{l}\text { Canada was my } \\
\text { first choice }\end{array}$} & \multicolumn{12}{|c|}{ Country of origin } \\
\hline & \multicolumn{2}{|c|}{ China } & \multicolumn{2}{|c|}{ Hong Kong } & \multicolumn{2}{|c|}{ Japan } & \multicolumn{2}{|c|}{ Korea } & \multicolumn{2}{|c|}{ Taiwan } & \multicolumn{2}{|c|}{ Total } \\
\hline & $N$ & $\%$ & $N$ & $\%$ & $N$ & $\%$ & $N$ & $\%$ & $N$ & $\%$ & $N$ & $\%$ \\
\hline No & 56 & 63 & 1 & 17 & 2 & 9 & 3 & 30 & 5 & 50 & 67 & 49 \\
\hline Yes & 33 & 37 & 5 & 83 & 21 & 91 & 7 & 70 & 5 & 50 & 71 & 51 \\
\hline Missing & & & & & 1 & & & & 1 & & 2 & \\
\hline Total & 89 & 100 & 6 & 100 & 23 & 100 & 10 & 100 & 10 & 100 & 138 & 100 \\
\hline
\end{tabular}


States was the preferred country for graduate studies for this sample.

Factors influencing study abroad The decision to undertake overseas graduate study is influenced by three domains of factors-(1) student characteristics/motivation, (2) external push-pull factors related to home-host countries, which can be viewed as a set of factors related to internationalization and globalization, and (3) encouragement from significant others (refer to Table 3). The respondents reported that personal

Table 3: Summary of factors influencing the decision to study abroad

\begin{tabular}{|c|c|c|c|c|c|}
\hline & $\mathbf{M}$ & SD & $\begin{array}{l}\text { Country } \\
\text { of origin }\end{array}$ & $\begin{array}{l}\text { Types of } \\
\text { programs }\end{array}$ & $\begin{array}{l}\text { Fields of } \\
\text { study }\end{array}$ \\
\hline \multicolumn{6}{|l|}{ Student characteristics and motivations } \\
\hline I want an advanced degree for personal satisfaction & 4.21 & 1.05 & & & \\
\hline My profession requires an advanced degree & 3.98 & 1.18 & $\checkmark$ & $\mathrm{R}$ & \\
\hline $\begin{array}{l}\text { Foreign advanced degrees improve job prospects/the } \\
\text { chance of receiving a good salary and promotions }\end{array}$ & 3.93 & 1.09 & $\checkmark$ & & $\checkmark$ \\
\hline I value an advanced degree from a Western country & 3.77 & 1.15 & $\checkmark$ & & $\checkmark$ \\
\hline The opportunity to gain freedom from family & 1.88 & 1.25 & & & \\
\hline \multicolumn{6}{|l|}{ External push-pull factors (Internationalization \& globalization) } \\
\hline Foreign language skills are desirable & 4.14 & 0.95 & $\checkmark$ & & $\checkmark$ \\
\hline The opportunity to experience a Western culture & 3.88 & 1.08 & $\checkmark$ & & \\
\hline $\begin{array}{l}\text { The work experience abroad is valued by my } \\
\text { home country }\end{array}$ & 3.85 & 1.09 & $\checkmark$ & & $\checkmark$ \\
\hline $\begin{array}{l}\text { Prospects of better employment and higher salary } \\
\text { after study abroad }\end{array}$ & 3.79 & 1.13 & $\checkmark$ & & \\
\hline $\begin{array}{l}\text { The foreign degrees are prestigious or valued by my } \\
\text { home country }\end{array}$ & 3.77 & 1.16 & $\checkmark$ & & $\checkmark$ \\
\hline International education is valued by my home country & 3.71 & 1.13 & $\checkmark$ & & $\checkmark$ \\
\hline Desired education not available & 2.94 & 1.51 & $\checkmark$ & & $\checkmark$ \\
\hline Home country lacks research facilities & 2.83 & 1.39 & & & $\checkmark$ \\
\hline Limited career prospects at home & 2.47 & 1.22 & & & \\
\hline Financial support from home government or agency & 2.05 & 1.55 & $\checkmark$ & & \\
\hline Uncertain political situation & 1.69 & 1.09 & $\checkmark$ & & \\
\hline \multicolumn{6}{|l|}{ Encouragement from significant others } \\
\hline Family/Spouse & 3.57 & 1.34 & & & $\checkmark$ \\
\hline Other Students/Friends & 3.18 & 1.30 & & $\mathrm{R}$ & \\
\hline Professors & 3.11 & 1.51 & $\checkmark$ & $\mathrm{R}$ & \\
\hline Alumni & 2.40 & 1.32 & & $\mathrm{R}$ & \\
\hline Relatives in the host country & 2.11 & 1.39 & $\checkmark$ & & \\
\hline Sponsor & 1.85 & 1.29 & & & \\
\hline Employers & 1.79 & 1.11 & $\checkmark$ & & \\
\hline
\end{tabular}

$p<0.05$

$\mathrm{M}-$ Mean is calculated based on a five-point Likert scale, ranging from " 5 -very important" to " 1 -not important", and an option of "N/A—not applicable"

" $\checkmark$ "-Significant difference among independent variables (e.g. country of origin and fields of study)

" $\mathrm{R}$ "-Students enrolled in research programs considered the factor as having greater importance than students enrolled in professional programs 
motivation was the most important driving force for the study-abroad decision.

In reviewing the external push-pull factors related to home country and Canada and the impact of internationalization and globalization on study abroad, it is worth noting that positive push factors exerted more influence than negative push factors in making the study-abroad decision. These international students reported that foreign language skills were desirable, and that the favorable perception of international education and foreign working experience by their home country had a significant influence in their study-abroad decision. It is worth noting that these positive factors, such as culturel language, economics, and academic factors, exerted more influence in making the study-abroad decision than negative factors, such as desired education not available, limited career prospects at home, and uncertain political situation.

Students enrolled in a research program reported the strong influence of encouragement from professors to pursue foreign education, while graduate students in professional programs ranked encouragement from professors as being of low importance. "Family (children)/spouse" was identified by some married students as a factor influencing the study-abroad decision, suggesting a possible intention to immigrate. Students studying in business programs reported factors related to internationalization and globalization, such as acquiring foreign language skills, future job prospects, and working-abroad experience, to be of high importance in influencing the study-abroad decision.
There is a significant difference by country of origin in the perceived benefits of studying abroad. Studying abroad was viewed positively in China, Korea, and Taiwan, but negatively in Japan. International graduate students from Japan tended to rank low in importance the value or economic benefits of foreign education in their society, indicating a "reverse push" factor from their country because Japanese society places less importance on the foreign graduate education. What motivated Japanese graduate students to study abroad was mostly encouragement from their professors, as this factor has been shown to be high in importance $(4.18$ out of 5 on the Likert Scale) in influencing their study-abroad decision. This suggests that when considering studying abroad, Japanese students are influenced by or more likely to respond to the activities related to internationalization, such as faculty and/or student exchange programs.

\section{Factors influencing choice of Canada}

The choice of Canada was influenced by the factors related to (1) the characteristics of Canada (e.g. environment), (2) external push-pull factors (e.g. economics of education, visa/immigration, marketing and information), and (3) significant others. Among the three sets of factors, the characteristics of Canada, which, in part, can be viewed as the effects of internationalization and globalization, had the most important influence on these students' choice of Canada, followed by the external push-pull factors, and then by significant others (refer to Table 4). 
Table 4: Summary of factors influencing the decision to study abroad

\begin{tabular}{|c|c|c|c|c|c|c|}
\hline & $\mathbf{M}$ & SD & $\begin{array}{l}\text { Country } \\
\text { of origin }\end{array}$ & $\begin{array}{l}\text { Canada is my } \\
\text { first choice }\end{array}$ & $\begin{array}{l}\text { Types of } \\
\text { programs }\end{array}$ & $\begin{array}{l}\text { Fields } \\
\text { of study }\end{array}$ \\
\hline \multicolumn{7}{|l|}{ Factors related to characteristics of Canada } \\
\hline Perceived as a safe place to study & 3.74 & 1.14 & $\checkmark$ & Yes & & $\checkmark$ \\
\hline Perceived as a studious environment & 3.49 & 1.16 & $\checkmark$ & Yes & & $\checkmark$ \\
\hline Diverse and multicultural environment & 3.40 & 1.20 & & Yes & & $\checkmark$ \\
\hline $\begin{array}{l}\text { Canada's quality of life and health of } \\
\text { the environment }\end{array}$ & 3.32 & 1.22 & & & & \\
\hline $\begin{array}{l}\text { The quality of the professional working } \\
\text { environment }\end{array}$ & 2.96 & 1.35 & & & & $\checkmark$ \\
\hline Perceived as an exciting place to live & 2.75 & 1.17 & & & & \\
\hline $\begin{array}{l}\text { The uniqueness of Canadian culture } \\
\text { and bilingualism are valued }\end{array}$ & 2.50 & 1.25 & $\checkmark$ & & & $\checkmark$ \\
\hline $\begin{array}{l}\text { Canada has strong economic ties with } \\
\text { my home country }\end{array}$ & 1.84 & 0.91 & & & & \\
\hline $\begin{array}{l}\text { Canada has strong political ties with } \\
\text { my home country }\end{array}$ & 1.67 & 0.89 & & & & \\
\hline $\begin{array}{l}\text { The Canadian educational system is similar } \\
\text { to the one in my country }\end{array}$ & 1.64 & 0.90 & $\checkmark$ & & $\mathrm{R}$ & \\
\hline \multicolumn{7}{|c|}{ External push-pull factors (Economics, marketing, and information) } \\
\hline $\begin{array}{l}\text { Canadian degrees provide greater mobility } \\
\text { for my future career/work }\end{array}$ & 3.14 & 1.22 & & & & \\
\hline The ease and speed of the visa process & 3.07 & 1.43 & $\checkmark$ & No & & $\checkmark$ \\
\hline Lower tuition costs & 3.02 & 1.45 & $\checkmark$ & & $\mathrm{P}$ & \\
\hline Proximity to the United States & 3.01 & 1.35 & $\checkmark$ & No & & $\checkmark$ \\
\hline $\begin{array}{l}\text { Information on study in Canada easily } \\
\text { obtained from the internet }\end{array}$ & 2.98 & 1.28 & $\checkmark$ & & & \\
\hline $\begin{array}{l}\text { The possibility of applying for immigrant } \\
\text { status }\end{array}$ & 2.96 & 1.38 & $\checkmark$ & No & & $\checkmark$ \\
\hline Lower living expenses & 2.82 & 1.41 & $\checkmark$ & & $\mathrm{P}$ & \\
\hline $\begin{array}{l}\text { The Canadian degrees are prestigious } \\
\text { and valued by my country }\end{array}$ & 2.81 & 1.16 & $\checkmark$ & & $\mathrm{R}$ & $\checkmark$ \\
\hline $\begin{array}{l}\text { Canadian graduate programs have } \\
\text { a good reputation }\end{array}$ & 2.78 & 1.17 & & & $\mathrm{R}$ & $\checkmark$ \\
\hline $\begin{array}{l}\text { Canadian education is perceived as } \\
\text { high quality in my country }\end{array}$ & 2.73 & 1.06 & & & $\mathrm{R}$ & $\checkmark$ \\
\hline $\begin{array}{l}\text { It is easy to obtain information about } \\
\text { Canada in my home country }\end{array}$ & 2.29 & 1.12 & $\checkmark$ & & & $\checkmark$ \\
\hline $\begin{array}{l}\text { Information on study in Canada obtained } \\
\text { from university calendars }\end{array}$ & 2.22 & 1.10 & & & & $\checkmark$ \\
\hline $\begin{array}{l}\text { Information on study in Canada easily } \\
\text { obtained from Canadian agencies in my } \\
\text { country }\end{array}$ & 2.21 & 1.11 & $\checkmark$ & & & \\
\hline $\begin{array}{l}\text { Information on study in Canada obtained } \\
\text { from education fairs }\end{array}$ & 2.09 & 1.08 & & & & \\
\hline \multicolumn{7}{|l|}{ Factors related to significant others } \\
\hline $\begin{array}{l}\text { My friends recommended, studied or } \\
\text { planned to study in Canada }\end{array}$ & 2.49 & 1.30 & $\checkmark$ & & & \\
\hline $\begin{array}{l}\text { My professors recommended or studied } \\
\text { in Canada }\end{array}$ & 2.34 & 1.53 & $\checkmark$ & Yes & & \\
\hline
\end{tabular}


Table 4: Continued

\begin{tabular}{lllllll}
\hline & M & SD & $\begin{array}{l}\text { Country } \\
\text { of origin }\end{array}$ & $\begin{array}{l}\text { Canada is my } \\
\text { first choice }\end{array}$ & $\begin{array}{l}\text { Types of } \\
\text { programs }\end{array}$ & $\begin{array}{l}\text { Fields } \\
\text { of study }\end{array}$ \\
\hline $\begin{array}{l}\text { I have family members or relatives living } \\
\text { in Canada }\end{array}$ & 2.19 & 1.49 & $\checkmark$ & Yes & $\mathrm{R}$ & $\checkmark$ \\
$\begin{array}{l}\text { I have friends living in Canada } \\
\begin{array}{l}\text { My spouse recommended, studied } \\
\text { or planned to study in Canada }\end{array}\end{array}$ & 2.15 & 1.30 & $\checkmark$ & Yes \\
\begin{tabular}{l} 
My sponsor chose Canada \\
\hline
\end{tabular} & 1.71 & 1.38 & & & & \\
\hline
\end{tabular}

$p<0.05$

" $\checkmark$ "-Significant difference among independent variables (e.g. country of origin and fields of study)

"Yes"-Respondents who said "Canada was their 1st choice" reported the factor and "No"-Respondents who said "Canada was NOT their 1st choice" considered the factor as having greater importance

" $\mathrm{R}$ "-Students enrolled in research programs and "P"—students enrolled in professional programs considered the factor as having greater importance

Most survey participants had a favorable impression of the Canadian environment. Those who said that Canada was their first-choice country typically reported that they came to Canada because of the positive Canadian Environment-safe, diverse, and multicultural. This indicates that their personal preferences were aligned with the unique features and social philosophy that Canada has to offer. On the other hand, those who reported that Canada was not their first-choice country chose to come to Canada for utilitarian reasons, such as ease of visa/immigration and proximity to the US.

There were differences in how these students viewed the importance of these three sets of factors in choosing Canada, especially in the external push-pull factors and significant others. Graduate students enrolled in research programs ranked the factors related to the characteristics of Canada ahead of factors related to the economics of education, marketing, or information (e.g. costs/price of education). They differed from graduate professional students in factors such as the perception of the Canadian environment and the quality/ reputation of Canadian education, by placing more importance on these factors. They also ranked their professors' recommendations as having a more important influence on their choice of Canada than the professional students. Graduate students enrolled in professional programs, on the other hand, looked for a high-perceived quality of education at competitive costs, as they ranked lower tuition costs and lower living expenses of high importance. They also ranked professors' recommendations with low importance.

Many Chinese students reported their preference of the United States as a destination, and they also ranked visa/immigration as one of the most important factors in choosing Canada. This indicates that in the postSeptember 11 era, visa and immigration considerations are of great importance in choosing Canada for particular groups of students, because they were not able to obtain US student visas, and as a consequence, they accepted Canada as their second 
choice due to the ease and speed of the Canadian visa process.

\section{Factors influencing choice of an institution}

The four key influences of the choice of an institution are: (1) external push-pull factors associated with academic pulling factors (e.g. quality, reputation/ranking, research, and faculty), (2) external push-pull factors associated with administrative pulling factors (e.g. financial aid, tuition, admissions, marketing, and information), (3) external push-pull factors associated with environment and location, and (4) significant others (refer to Table 5).

The academic pulling factors were ranked with very high importance, followed by the administrative pulling factors, environment and location, and significant others. In general, the university reputation/quality/ranking was ranked ahead of the program reputation/quality/ranking. In essence, these are core factors that pervade the entire study-abroad process, and that display an important pulling effect in drawing international graduate students to Canada and to Canadian graduate schools.

Students in research programs reported that the most important factor in choosing their school was the availability of financial aid; however, except for this funding factor, they ranked factors associated with academic pulling factors with more importance than the ones associated with administrative pulling factors. Unlike the graduate professional students, they placed higher importance on faculty reputation and quality/reputation of university than on the ranking of the university and program. They reported that recommendations from professors and alumni, and the relationship and interaction with faculty and staff were important factors influencing their choice of a graduate school. Some students reported in the interviews that they came to Canada solely because they wanted to study under their professor/ supervisor in specific research areas.

Students enrolled in professional programs ranked factors such as the ranking of the program and affordability of tuition with high importance in choosing a Canadian graduate school, in part due to the availability of program ranking information and marketing efforts (e.g. MBA Tours) done by the program. Students from China, Hong Kong, and Taiwan rated the importance of the university and program ranking higher than students from Japan and Korea. It was found that the ranking information was important not so much for reducing risks, but more for economic and return on investment purposes. These students perceived that a graduate degree from a top-ranked engineering or a business school/program would improve their future career and job prospects. Overall, although the administrative factors related to funding, financial aid, and tuition were of great importance in pulling international students to a Canadian graduate school, they were secondary only to the academic pulling factors.

Students enrolled in professional programs, in particular business students, reported that factors such as the location of the university and the potential for future work in the same city were more important than for 
Table 5: Summary of factors influencing the choice of an institution

\begin{tabular}{|c|c|c|c|c|c|c|c|}
\hline & $\mathbf{M}$ & SD & $\begin{array}{l}\text { Country } \\
\text { of origin }\end{array}$ & $\begin{array}{l}\text { Canada is my } \\
\text { first choice }\end{array}$ & $\begin{array}{l}\text { Types of } \\
\text { programs }\end{array}$ & $\begin{array}{l}\text { Fields of } \\
\text { study }\end{array}$ & University \\
\hline \multicolumn{8}{|c|}{ External push-pull factors (Academic pulling) } \\
\hline The reputation of the university & 4.12 & 1.03 & $\checkmark$ & & & $\checkmark$ & $\mathrm{U}$ of $\mathrm{T}$ \\
\hline The quality of the university & 4.12 & 0.99 & & & $\mathrm{R}$ & $\checkmark$ & $\mathrm{U}$ of $\mathrm{T}$ \\
\hline The quality of the program & 4.09 & 1.09 & & & & $\checkmark$ & \\
\hline The reputation of the program & 4.04 & 1.11 & & & & $\checkmark$ & \\
\hline The ranking of the university & 3.94 & 1.11 & $\checkmark$ & No & & $\checkmark$ & $\mathrm{U}$ of $\mathrm{T}$ \\
\hline The ranking of the program & 3.87 & 1.16 & $\checkmark$ & No & $\mathrm{P}$ & $\checkmark$ & \\
\hline $\begin{array}{l}\text { The reputation of the faculty } \\
\text { in my program }\end{array}$ & 3.76 & 1.26 & & & $\mathrm{R}$ & $\checkmark$ & $\mathrm{U}$ of $\mathrm{T}$ \\
\hline \multicolumn{8}{|c|}{ External push-pull factors (Administrative pulling) } \\
\hline The availability of financial aid & 4.11 & 1.28 & $\checkmark$ & Yes & $\mathrm{R}$ & $\checkmark$ & \\
\hline Affordable tuition fees & 3.83 & 1.24 & & & & & York \\
\hline $\begin{array}{l}\text { The degree from my university } \\
\text { improves my future career and } \\
\text { job prospects }\end{array}$ & 3.67 & 1.19 & $\checkmark$ & & & $\checkmark$ & $\mathrm{U}$ of $\mathrm{T}$ \\
\hline $\begin{array}{l}\text { A wider program and course } \\
\text { offering }\end{array}$ & 3.62 & 1.15 & & & & & \\
\hline $\begin{array}{l}\text { Positive relationship between } \\
\text { faculty and students }\end{array}$ & 3.51 & 1.29 & $\checkmark$ & & & $\checkmark$ & \\
\hline $\begin{array}{l}\text { The degree from my university } \\
\text { is highly marketable }\end{array}$ & 3.22 & 1.40 & & & & & $\mathrm{U}$ of $\mathrm{T}$ \\
\hline $\begin{array}{l}\text { Previous correspondence or contact } \\
\text { with the faculty }\end{array}$ & 3.17 & 1.41 & & & & & \\
\hline $\begin{array}{l}\text { Positive interaction with university } \\
\text { personnel }\end{array}$ & 3.15 & 1.30 & & & $\mathrm{R}$ & $\checkmark$ & $\mathrm{U}$ of $\mathrm{T}$ \\
\hline $\begin{array}{l}\text { Program requirements (residency/ } \\
\text { length) }\end{array}$ & 3.11 & 1.25 & $\checkmark$ & & & & \\
\hline $\begin{array}{l}\text { Recognition of my previous } \\
\text { credentials }\end{array}$ & 2.97 & 1.26 & & & & $\checkmark$ & \\
\hline $\begin{array}{l}\text { The speed of the application } \\
\text { process }\end{array}$ & 2.87 & 1.25 & & & & $\checkmark$ & \\
\hline Not accepted elsewhere & 2.74 & 1.61 & & & & & \\
\hline $\begin{array}{l}\text { Marketing information obtained } \\
\text { from this university }\end{array}$ & 2.05 & 1.10 & $\checkmark$ & & & & \\
\hline $\begin{array}{l}\text { Information obtained from the } \\
\text { Peterson's Guide }\end{array}$ & 2.05 & 1.18 & & & & & \\
\hline $\begin{array}{l}\text { I have studied at this university } \\
\text { before }\end{array}$ & 2.04 & 1.54 & $\checkmark$ & Yes & & & \\
\hline \multicolumn{8}{|c|}{ External push-pull factors (Environment and location) } \\
\hline $\begin{array}{l}\text { The city where my university is } \\
\text { located is safe }\end{array}$ & 3.42 & 1.19 & & & & $\checkmark$ & $\mathrm{U}$ of $\mathrm{T}$ \\
\hline $\begin{array}{l}\text { There is no discrimination against } \\
\text { me at this university }\end{array}$ & 3.29 & 1.30 & & & & $\checkmark$ & \\
\hline The location of the university & 3.27 & 1.24 & $\checkmark$ & Yes & $\mathrm{P}$ & $\checkmark$ & \\
\hline $\begin{array}{l}\text { The diversity of the city where } \\
\text { my university is located }\end{array}$ & 3.20 & 1.31 & $\checkmark$ & & & & \\
\hline $\begin{array}{l}\text { The possibility of staying and } \\
\text { working in the city where } \\
\text { my university is located after } \\
\text { graduation }\end{array}$ & 2.88 & 1.37 & $\checkmark$ & & $\mathrm{P}$ & & \\
\hline
\end{tabular}


Table 5: Continued

\begin{tabular}{|c|c|c|c|c|c|c|c|}
\hline & $\mathbf{M}$ & SD & $\begin{array}{l}\text { Country } \\
\text { of origin }\end{array}$ & $\begin{array}{l}\text { Canada is my } \\
\text { first choice }\end{array}$ & $\begin{array}{l}\text { Types of } \\
\text { programs }\end{array}$ & $\begin{array}{l}\text { Fields of } \\
\text { study }\end{array}$ & University \\
\hline \multicolumn{8}{|l|}{ Factors related to significant others } \\
\hline $\begin{array}{l}\text { Recommendation from my } \\
\text { professor in my country }\end{array}$ & 2.74 & 1.66 & & Yes & $\mathrm{R}$ & & $\mathrm{U}$ of $\mathrm{T}$ \\
\hline $\begin{array}{l}\text { Recommendation from my } \\
\text { friends/alumni }\end{array}$ & 2.73 & 1.48 & & & & & \\
\hline $\begin{array}{l}\text { Recommendation from my } \\
\text { professor in Canada }\end{array}$ & 2.69 & 1.54 & & & $\mathrm{R}$ & & \\
\hline $\begin{array}{l}\text { My friends have studied or are } \\
\text { studying at this university }\end{array}$ & 2.10 & 1.34 & & & & & $\mathrm{U}$ of $\mathrm{T}$ \\
\hline $\begin{array}{l}\text { Recommendation from my } \\
\text { family/spouse }\end{array}$ & 2.08 & 1.33 & & Yes & & & \\
\hline $\begin{array}{l}\text { Recommendation from my } \\
\text { sponsor }\end{array}$ & 1.77 & 1.25 & & Yes & & & \\
\hline
\end{tabular}

$p<0.05$ (Codes are the same as in Table 3 and Table 4.)

"U of T"-Respondents enrolled at the University of Toronto considered the factor as having greater importance than those enrolled at York University

students enrolled in research programs. International graduate students were concerned about safety, discrimination and tolerance (being accepted), diversity, and multiculturalism within a city and within an institution. The findings show that there was some correlation between Florida's "creative capital" theory and college choice.

\section{Summary of research findings from the survey}

The research findings show that institutional characteristics (both academic and administrative) have the strongest influence on international students when choosing a Canadian graduate school, followed by factors related to the characteristics of Canada (e.g. environment, economics of education, and visa/immigration), and then factors related to study-abroad decisions. While the pulling factors from Canada and Canadian higher educational institutions exerted the most significant influence on international students' enrollment decisions, there was, in fact, another set of strong push factors (e.g. visa/ immigration) from third countries, such as the United States, to push international students toward Canada and Canadian graduate schools, as reported by those who said that Canada was not their first-choice country.

The push-pull model has been primarily used in the literature to explain international students' choice of a country and decision-making process in the first two stages"predisposition" and "search/selection/ application." Adding to previous studies, this study has used the pushpull model to understand the student's choice of a Canadian graduate school at all three stages. To provide a summary of the factors studied in this research, Figure 2 depicts the strength of the pulling factors in making an enrollment decision of a Canadian graduate school. There are four levels of circles in Figure 2. The core 


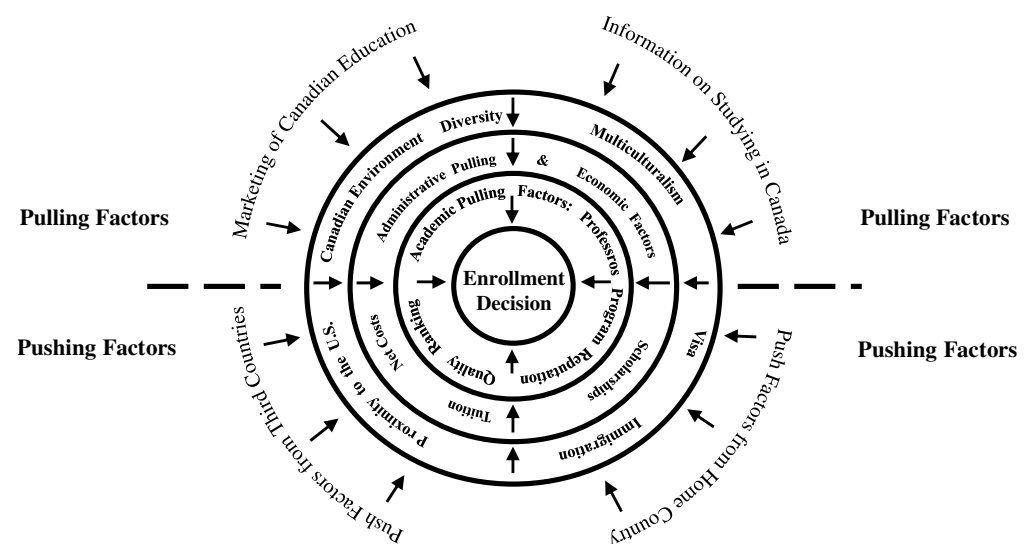

Figure 2: The strength of the factors in choosing a Canadian graduate school

represents the enrollment decision. The innermost circle, Academic Pulling Factors, is the dominant influence, followed by Administrative Pulling and Economic Factors in the middle circle.

The outermost circle represents factors, such as Canadian Environment, Visa/Immigration, and Proximity to the US, with a moderate influence on the enrollment decision. Outside of the circles, at the periphery, four factors show a weak to moderate influence on the choice of Canadian graduate school. They are Marketing of Canadian Education, Information on Studying in Canada, Push Factors from Home Country to Canada, and Push Factors from Third Countries to Canada. The top half of the periphery represents the pulling factors, while the bottom half of the periphery represents the pushing factors.

\section{Findings from the Interviews-Process of Undertaking Overseas Graduate Studies}

The in-depth interviews were used mainly to understand the process of undertaking overseas graduate studies, to verify data collected from the survey questionnaire, and to gain insights into the significant differences among country of origin and between graduate students enrolled in research programs and professional programs.

Although some international students did follow the sequence of deciding to study abroad, then choosing a host country, and finally choosing an institution, this study finds that the study-abroad process was not necessarily ordered by country, institution, and program, as suggested by Mazzarol and Soutar's (2002b) three-stage decision process or by Neice and Braun's (1977) “decision hierarchy" of a foreign study pathway. The research findings only suggest that the three-stage temporal process is predisposition, search/selection/ application, and choice. First is the so-called "predisposition" stage, which includes the personal needs assessment, the search and acquisition of information on study abroad, and the decision to study abroad; second is the "search/selection/application" stage, which includes the acquisition of 
information on countries, institutions, programs, locations and costs, the comparison and analysis of all the features offered by each country, institution, program, location, and by the end of this stage, arriving at a decision regarding where to study, as well as which schools and how many schools to apply to; and third is the "choice" stage, which includes the assessment of institutional characteristics (academic and administration), country-specific features (environment, visa/ immigration, economic/costs), and location.

Many participants in this research claimed that choosing a program was the first step in the process, and once they determined the program of study, they then tended to consider multiple institutions in various countries and cities, as they applied to programs and institutions in different countries and cities at the same time. In other words, the choice of a country is not an exclusive stage of the process, and the choice of a country does not have to be made before the choice of an institution, or vice versa. The program decision guided the whole studyabroad process-from information collection, to application, and through the choice stages. In fact, before proceeding to the "search/selection/ application" stage, these students had already determined the program of study, and other factors-country, institution, and city-interplay simultaneously at the "search/selection/ application" and "choice" stages. The majority of international students considered the program characteristics first because the program of study is the core of the overseas study experience. The program specialization or uniqueness determined which countries and institutions to pursue for further information, and a change in program of study may have also changed the destination country and institution. For example, one Korean student planned to study social philosophy in Germany, but later changed his mind to study political economy in North America, as he believed that studies in social philosophy were more advanced in Germany, while studies in political economy were more advanced in North America. It is worth noting that country and university were considered closely when deciding where and what to study. For example, some international students found that programs such as language education or sociology specializing in the immigrant population were far more advanced in Canada than in other English-speaking countries. A few programs were only offered in Canada, and so by default Canada became the only country to consider.

Based on the above findings, The (Original) Synthesis Model (shown in Figure 1) was modified (see Figure 3The (Modified) Synthesis Model): before the "predisposition" stage, the program of studies is first determined. At the "predisposition" stage and "choice" stage, the focus of programs (i.e. research programs versus professional programs) dominated the overseas graduate study process. It influenced the approaches to the "search/selection/application" of country, institution, and city, and the "choice" of enrollment decision. In the "search/selection/application" stage, country, institution, and city factors interacted simultaneously; in fact, the process is more dynamic and 


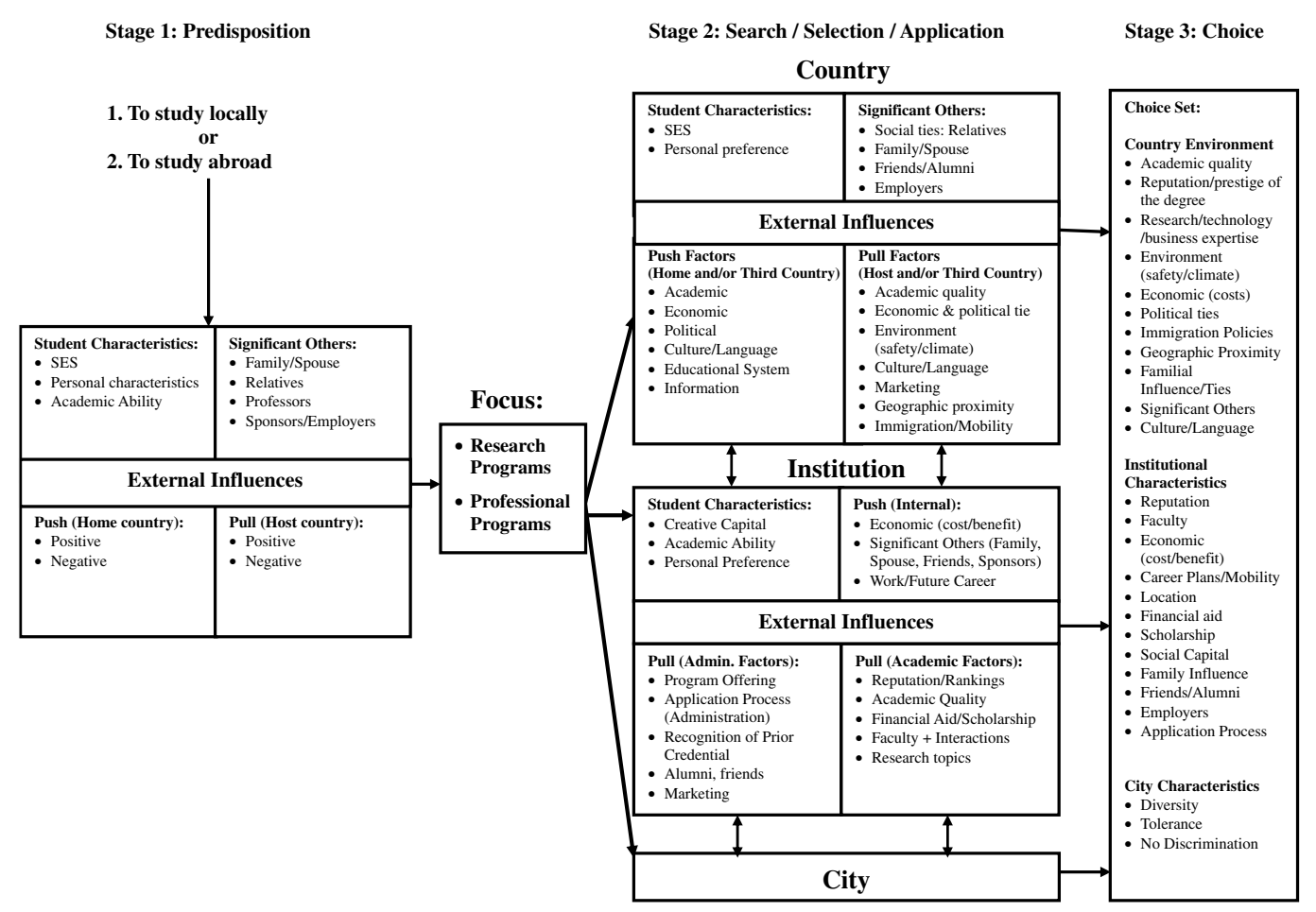

Figure 3: The (Modified) synthesis model

interactive among country, institution and city, than the original synthesis model depicts, where the country was selected first, and then the institution.

\section{The "predisposition" stage}

At the "predisposition" stage, especially in the personal needs assessment step, undertaking overseas graduate studies was most influenced by personal driving forces, consisting of five main sets of factors: (1) student characteristics (e.g. academic ability), (2) personal motivations (e.g. language skills acquisition, home countries value foreign education, etc.), (3) careerrelated factors (e.g. better job prospects), (4) academic-related factors (e.g. research interests, advanced technology, and research in the West), and (5) significant others (e.g.

influenced by peers, family, supervisors, etc). More often, the decision was made based on some combination of these five categories of factors. In order to satisfy these personal needs, potential international graduate students made inquiries about studying abroad and began gathering information.

As can be seen from the survey findings, there were significant differences when viewing the benefits of studying abroad among international graduate students when divided by country of origin, and this was further verified by the interviews. In Chinese, Korean, and Taiwanese societies, studying abroad was viewed 
as a positive endeavor, while it was viewed as a negative undertaking by Japanese society. In fact, many Japanese students mentioned that overseas graduate study was not considered a favorable undertaking. Some said a foreign education could actually have a negative effect on their future career if they return to Japan. According to Japanese students, Japan is a closed society, and there are different built-in networks in various fields. A western-educated professional returning to Japan may well have a hard time being accepted. They would be considered as "outsiders," unless they graduated from some very famous university that most Japanese people have heard about. Two Japanese students commented ${ }^{2}$ :

If they are pretty good in Japan, they don't really want to go out, because they can go to good public universities... I think within Japanese society, many people think going to Japanese graduate schools is better... because they kind of know you go to famous university, you can get this job, or that job... Japanese society is less open to foreign education...

For Japanese students to study abroad is not a good idea, if you want to go back to Japan. One thing you are older than the rest of Japanese who have same degree. Other thing is they look at you like you are from outside. They don't want to take you and they don't want to give you a job. You are from outside, you have different way of doing things. Employers would prefer Japanese Ph.D. to foreign Ph.D., and masters as well. If you want to get a job in Japan, it is better for a student to study master program in Japan. Also, the connection is very important, such as network of people is very important to get a job. If you are abroad, it is very hard to have the network in Japanese society. If I did my graduate work in Japan, I would have contact with lots of Japanese professors. I can do more networking there, so I will have higher opportunity. It is not that Japanese education is better than the western education; it is that the culture of the work place is important.

\section{The "search/selection/application" stage}

After making the study-abroad decision, international graduate students proceed to the "search/ selection/application" stage, and then the "choice" stage. They go about searching for study abroad information in various ways-media (electronic and print format), significant others (e.g. family members, friends, professors, authors of journals or books, etc.), and organizations (e.g. embassies/consulates and libraries). Most of the students stated that they used the internet to search for study abroad and programs/ institutions information. They found that the internet was the most useful way of obtaining general information about study abroad, and specific information regarding programs/ institutions, rankings, and reputation. Printed materials such as school brochures and calendars were considered helpful in obtaining detailed information on the program of study, such as program concentration, course descriptions, special research projects, and research focus. 
At the "search/selection/application" stage, there was a significant difference in approach on gathering information and making applications depending on the program of study, that is research programs versus professional programs. Some research graduate students commented on their decisionmaking process as being determined by their research interests and/or guided by their professors/supervisors, and others reported that they e-mailed the authors of journal articles and books whose research areas were of interest, or met their current professors in conferences or in their previous exchange studies. They asked these authors/professors for assistance in directing their search toward a particular program of study and in providing recommendations as to which schools to apply to. For example, one student commented:

How did I know which schools to apply? Through my professors, and the Internet, and I had already read the books and articles of professors that I wanted to work with... I contacted the authors of those papers and sent e-mails to them. Also, some North American scientists visited my university to do some seminars, and I talked to them and asked them how I can get to the States to study. They recommended that I can talk to this person, so I looked at the website and contacted those people. They are professors at the universities... The Internet is very important and it is the only source... How I chose the school was based on the professors, like my research interest is within professor's research interest. I just looked at the professors...
Internationalization activities, such as faculty exchanges, collaborations, attending international conferences, and publishing research papers, played a crucial role in guiding these international graduate students' search, application, and choice process. This suggests that this group of students tended to respond to the effect of internationalization; moreover, internationalization activities, such as international conferences, presentations by guest speakers, and exchange programs for both faculty and students, are crucial and beneficial not only to the institutions in promoting their profiles but also to international students enrolled in research programs in gathering study-abroad information. The following comments illustrate how internationalization activities guided these international graduate students' decision-making process of a Canadian graduate school.

I talked with my supervisors about which schools should be good for my Ph.D. My supervisor was a visiting scholar at OISE, and she told me that this institution is very good for my future study... I prefer language courses in Canada. Canada has bilingual policy and it is famous for bilingual education, so I wanted to come to Canada... I also included universities in England, but I applied to $\mathrm{U}$ of $\mathrm{T}$ first.

For the political science program in Canada, I worked with one professor in the Department of Economics at Seoul National University. He presented his article in the Department of Political Science at York University in 1998. I worked with that professor around that time, so I knew the political 
science program at York through this professor, and I found the information from the Internet... School ranking to me is not important. But, for other Korean students, in other fields, they would think ranking is important. For me, program and professors are more important... Professor, program, and then funding...

When searching for institutions, most international students enrolled in professional programs relied heavily on the institutional and program ranking, tuition, and location/environment information as their first screening process. Some MBA students reported that they attended MBA Tours or educational fairs to gather information, and considered these fairs to be like networking events for them to find school/program and application process information. They found that MBA Tours or fairs served as a screening function because they had opportunities to talk to the school representatives. One student commented that the MBA Tours were helpful because "if there are some schools you are interested, you can just go and ask them questions directly." This suggests that traditional marketing activities may be applicable to a very limited number of professional graduate programs, such as Master of Business Administration. The following comments were made by international students, enrolled in MBA programs:

I search the website, the ranking. I find York University, U of T, the Western Ontario University, and Queen's University. These four universities among the best schools in Canada in terms of MBA, so I checked their tuition, I find that York University can allow me to take the same degree at a lower rate. So, I just chose this school to apply, only one school.

Tuition cost is very important. When I decided to look into the Canadian schools, the tuition costs of other business schools, like Ivy, UT, really frightened me, there is no way to afford them, without any financial aid.

The major difference between the United States, England, and New Zealand, is that Canadian universities require lower tuition fee. Tuition fee is lower, is very important. Like in the United States, same school, same program, is almost like double or triple...

Location factors played an important role throughout the decision-making process as to search/select/application process, and again at the choice stage process. City factors exerted some influence in selecting schools for application, and the key characteristic was being a metropolitan city. The majority of students expressed a preference for attending a graduate school located in a metropolitan city, since they were used to living in a similar environment in their own country. The distance to home country was not mentioned as a factor, as many international students applied to universities in many regions of North America.

\section{The "choice" stage}

After students obtained offers of admission from universities, the process moved to the "choice" stage: 
international students revisited the same factors they considered during the "search/selection/application" stage, and made their final enrollment decision based on what each program, country, institution, and city had to offer. As mentioned above, at the "choice" stage, international students considered the program factors (e.g. faculty, research focus, program specialty, program reputation, and ranking), country factors (e.g. environment, visa/immigration, and cost of living), institution factors (e.g. quality, reputation, financial aid, or tuition), and city factors (e.g. location and diversity) simultaneously.

There were four main reasons for international students to choose Canada as a host country: (1) the Canadian environment, (2) the cost of living and tuition. (3) the Canadian educational system, and (4) the Canadian visa/immigration policy. The interview results verified Neice and Braun's finding that "Canada plays second fiddle to the United States" (pp. 48-50), in addition to verifying the survey findings. It is notable that every single Chinese interviewee commented on the difficulty of obtaining a US student visa. As a result, they found that although Canada was their second choice, it was in fact their only choice. Owing to the effect of the US visa policy, Canada indirectly benefited from an inflow of international graduate students who were not able to obtain US student visas. None of the other four groups of international students mentioned the issue of difficulty in obtaining US student visas.

Some of the factors of choosing an institution/program were the same as stated at the selection/application process stage. However, at this stage, the program characteristics (e.g. specialty, faculty research focus, and/or the research projects), the economics of the offer, and the speed of the admission offer were the main deciding factors, especially for students in research programs, while the ranking of the program, the cost/economic factors, and city characteristics/location factors were the main deciding factors for students who were self-funded in the professional programs. It is important to note that scholarship and financial aid were often stated as one of the most influential factors in making the enrollment decision. Indeed, many students would not have been able to afford the study, without sufficient scholarship or financial aid to cover tuition and basic living expenses. Financial aid was the most mentioned pulling factor and this was the final pull to entice international students to make the enrollment decision. However, interviews with various doctoral students also indicated that as long as they received a level of scholarship or financial aid that covered tuition fees and living expenses, amounts beyond that level did not appear to be influential, for example:

In terms of money, the United States programs offered more money than York. I gave those offers up because of my research field, and York University has more professors that I would like to work with.

It seems the research in US, at least in our domain, they have more funding from the companies. They have better environment. In my two years of master, I have participated 
in several conferences, so it gives me a chance to see the researchers in the US. I don't want to comment about that, but I don't appreciate their working style, they are not doing real research. But, at least in $\mathrm{U}$ of $\mathrm{T}$, in Canada, I see people they are doing real work, they are doing research, but not money driven. I love the research style in Canada more than in the States, even in the US they have better environment, they have more funding to give to graduate students, they have more comfortable life, but the atmosphere is different.

As mentioned above, these students reconsidered the city factors during the search/select/application stage, and again at the choice stage. All things being equal, these students would choose an institution located in a metropolitan area. They considered the various benefits of being in a metropolitan city such as Toronto-a multicultural environment where there was little discrimination, convenient public transportation, and lower living costs in comparison to other North American metropolitans.

\section{Discussion}

The intent of this section is to discuss the relevant information and themes that emerged from the interviews(1) why not other English-speaking countries, (2) internationalization versus marketing, and (3) the implications for education-exporting countries and higher educational institutions, as well as to conclude the discussion with a set of recommendations for educationexporting countries and their higher education institutions.

\section{Why not other English-speaking countries?}

While this study focused on the factors that influenced international students' choice of Canada and Canadian graduate school, the interviewees also shared their stories on why they did not choose other English-speaking countries. In fact, many international students considered other Englishspeaking countries while they were searching and gathering study-abroad information. The most frequently mentioned countries were Australia, the United Kingdom, and the United States. Some eliminated these countries as a destination for graduate studies at a later stage of the decision-making process. The common reasons that turned international students away from these countries included the higher cost of education, length of the program, academic credibility, research environment, political relations, discrimination, and visa availability. In effect, these reasons represented another set of negative push factors from third countries-international students were pushed away from them and pushed toward selecting Canadian graduate schools.

These international students said that they shied away from Australian graduate schools for two main reasons-academic year cycle and image problems. These international students found that the Australian academic year cycle did not coincide with the school year in their home countries, which was an important factor for those students who wanted to continue their graduate studies right after their undergraduate program. In addition, Australia's aggressive marketing and recruiting effort targeting undergraduate-level studies in 
the East Asian countries has had a negative impact on highly qualified potential graduate students. They saw Australian universities as mainly for under-prepared undergraduate students who could not pass university entrance examinations in their home countries. They associated this with poor quality or lack of academic credibility on the part of the university. This may in part explain why Australia has had a challenge in attracting highly qualified graduate students from these East Asian countries.

The universities in the United Kingdom were generally considered to be of high quality by these students. The most mentioned reasons for not choosing the British universities were the higher cost of living, high tuition fees, and the length of the program. A few MBA students commented on the length of the program at the British universities that were one year in length. They stated a preference for a two-year program, as they wanted to gain knowledge in the subject area, to experience the Western world, and to learn the English language. For many, a one-year study abroad was considered insufficient for doing all these things.

As discussed earlier, the United States was the first-choice country for many international students, which in itself represents a strong pull factor. However, there were factors that pushed international students away from choosing American universities including visa, political relations, research environment, fear of discrimination/not fitting in, and the higher cost.

Visa was the most mentioned reason for Chinese students not to go to the American universities. This is a strong negative push factor that pushed Chinese students away from the United States and pushed them toward Canada. Two students mentioned political relations and political stability as reasons for not choosing the United States as a host country, and they were concerned about security and safety. In the post-September 11 era, some international students prefer to pursue foreign graduate studies in a country perceived to be more peaceful, politically stable, and nondiscriminatory. They feel more than ever the importance of the diversity and tolerance of a society when choosing a host country.

International students, in general, considered the research environment to be better in the United States, mostly because there is more funding for research and closer ties to the technology and to corporations. However, a few international students stated that they preferred the research environment and the working atmosphere and style in Canadian graduate schools to their American counterparts, despite American universities offering more scholarships to their graduate students. A few of the Japanese students reported that their fear of discrimination or their fear of not fitting in were their main reasons for not choosing American graduate schools. The cost of education was an important factor especially for those self-funded professional students. Many students stated that the tuition fees in the United States were much higher, and they would get "the same degrees at a lower rate" in Canada.

These negative push factors from third countries made Canada and Canadian graduate schools the 
preferred host country and host institutions, respectively. It is apparent that these international graduate students regarded American education highly in terms of research capability, but they also considered Canadian graduate schools as strong substitutes because of the high quality of education. In addition, unlike Australia, Canada does not have an image problem. In comparing the cost of education, Canada compares favorably with the British and American schools. In considering all these factors, the cost of education factor needs close monitoring, as cost is a controllable factor and these international students are sensitive to the cost issue. Other factors, such as the cultural environment and the perception of quality, are difficult to manipulate.

The traditional push-pull model, originally used in the theory of migration to explain the factors between the home-host countries that influenced the movement of people, has to be broadened to understand international student flows and the international students' choice of a country. The research findings show that the push-pull forces are not limited to home and host countries, but are related to the geopolitical dynamics of home, host, and third countries. The third country may exert both pull and push forces during the international students' decision-making process, as exemplified by the situation between the United States and Canada-international graduate students were pulled to North America by the desirable features offered by the United States and its universities, but then, some were pushed away by the United States to Canada.

\section{Internationalization versus Marketing}

Internationalization and marketing are two different concepts; however, both concepts play a useful role in explaining international students' choice of a host country and a host institution. As revealed in the findings, market segments, for example, students enrolled in research programs versus professional programs, field of studies, or country of origin, also provided important insights for higher educational institutions to consider when they compete for and attract international graduate students. The findings illustrate that the effects of the internationalization of education are more applicable to international graduate students enrolled in research programs, while the applications of marketing strategies and tactics are more applicable to international students enrolled in professional programs.

The "activity" approach is most applicable to international students. In interviews in which they described how they chose to study at a Canadian graduate school, one of the very important pulling factors was meeting their current professor during "international" activities. The three most mentioned activities were international conferences, presentations by guest speakers, and exchange programs. Many of the international graduate students met their current professors at international conferences; some met their current professors at their home country where the latter were invited to be guest speakers; and some met their current professors because professors in their home country had exchanges or working experience with their current 
professors. A small percentage of students mentioned that they themselves had participated in exchange programs.

Internationalization activities benefit both higher educational institutions and international graduate students. Overall, as seen in the Canadian case, there are at least three major benefits of internationalization activities accruing to international graduate students throughout the whole process of overseas graduate study and beyond. First, these activities help Canadian higher educational institutions promote their profile and reputation, which helps increase awareness of Canadian graduate education among the international academic society. In turn, these activities are important to international students in gathering study-abroad information and in learning about new research projects/directions during the "predisposition" and "search/selection/ application" stages, and subsequently, in helping international students make enrollment decisions. Secondly, during their studies in Canada, international activities in the institution also provide all students and international students in particular with opportunities to gain knowledge in various subject areas from professors and students of different backgrounds. Finally, these international students are typically economically sensitive, and in general, they pay attention to the return on their investment. Most international graduate students agreed that they would like to work in an international environment in the future. This means that the more international activities the university and program arranged, the higher the profile they would enjoy and the more international employers would be familiar with graduates from these universities and programs. Consequently, international students benefit from possible future career enhancements and improved job prospects in an international setting.

Like internationalization, marketing has also played a significant role not only by providing professional students with information to support their decision-making but also in helping higher educational institutions to attract and recruit international students. The concept of market segmentations is crucial in this regard. Professional programs, such as the MBA, are very different from the research-intensive programs, and so the marketing strategy for the professional programs must be different. For example, MBA students found that MBA Fairs were helpful not only in gathering information but also in networking with the prospective school representatives; in addition, ranking information is also a crucial marketing tool, with a strong pulling effect on the application and choice decision. Research-oriented students found that journal articles and research papers in academic journals and other publications, which may be seen as one aspect of internationalization activities, were important marketing tools, as they could learn about the new research topics of particular faculty members. Any MBA offering business school that decides not to participate in an MBA Fair will miss out on the opportunity to increase program awareness and reach potential students, whether or not the events will directly result in enrollment. On the other hand, research-oriented programs participating in educational fairs will probably be wasting their 
resources because their target students will be unlikely to attend those fairs.

Based on the above discussion, internationalizing graduate education through activities such as international strategic alliances including collaborations in research and technology exchanges and international consortia, student, and academic staff movement represents a soft or an implicit way, and perhaps the best way, of marketing higher education to international students in research programs. Indeed, by participating in international activities such as conferences and faculty/student exchange programs, universities or particular programs are engaging in marketing their research capabilities and program quality, and in increasing their institutional profile; as a consequence, the core competencies of graduate education are promoted through the internationalization effort. Marketing, on the other hand, is an explicit approach to promoting higher education in general and to increasing awareness, which is important in attracting international students at all levels. As shown previously, it is apparent that factors such as Marketing of Canadian Education and Information on Studying in Canada played a small role in influencing students' choice of Canada and Canadian graduate school. This can be viewed as an opportunity for Canada to improve, thus yielding greater returns in pulling international graduate students to Canada. Although students can access information on studying in Canada online, it would be more convenient for many of them to talk to someone, such as alumni, in their home country or to get printed materials in their local language.
Making information available locally exerts a strong pulling effect initially that helps eliminate many barriers especially for those who have weak English skills.

In conclusion, the concepts of internationalization and marketing although different in nature, nonetheless act in combination in influencing international students' choice of a host country and a host institution. To forward the goal of attracting international graduate students and increasing enrollment numbers, it seems clear that internationalization efforts should be undertaken in a decentralized manner at the program level, while marketing and communication efforts should be undertaken at the institution or country level to increase the image and branding of a country and its higher education system.

\section{Implications for education- exporting countries and higher education institutions}

This section reviews the dynamics of important factors raised by international students that influenced their decisionmaking process and choice, and the implication of these factors for education-exporting countries and higher educational institutions. The key issues include (1) tuition fees and scholarships, (2) academic reputation/quality and core competencies of graduate education, (3) visa and immigration, and (4) recruitment of international graduate students.

\section{Tuition fees and scholarships}

Tuition fees and scholarships were the most discussed items during the 
interviews. As reported in the previous discussion, international students decided to come to Canada because they considered that the cost was lower or they received financial aid or scholarships. Contrary to the conventional perception that most of the international students are from higher socio-economic backgrounds in their society, many of these East-Asian international graduate students reported that their parents were not wealthy and/or their parents were not well educated. This is crucial in understanding this group of international students-they are different and should be treated differently from other international students.

They are different because despite higher educational institutions' expectations that international students would bring in revenue, these international graduate students depend on the institutions to provide them with financial support. In other words, the host institutions need to make an investment in these international graduate students. Without financial support such as scholarships or assistantships from the institutions, many of them would not be able to pursue graduate education. To be more specific, an offer of admission without a scholarship will definitely not draw international graduate students, especially research-oriented students. Many stated that they received offers from the British universities without scholarships, and decided not to accept these offers. Therefore, in order to increase the number of international graduate students, especially in the research programs, scholarships or assistantships are a requirement. However, the amount of the scholarship above the level required to pay tuition and basic necessities may not be a strong influencing factor in the enrollment decision. The extent of the influence of this excess amount is not the focus of this research and may warrant future study. Several students commented that they received higher scholarships in the United States; however, they chose to forfeit these larger scholarships and enrolled in Canadian graduate schools that offered them substantially lower scholarships. The common reasons are professors, program specialty, and research projects. This suggests that academic factors exerted a stronger influence in the enrollment decision than scholarship and financial aid factors.

Self-funded or masters' students, if they have excellent academic records, will be able to choose from a set of offers. Therefore, the tuition cost can be one of the important factors in making an enrollment decision. Again, the sensitivity of the tuition fee (in terms of the amount differential) on the choice of a graduate school is unknown. However, many international students in the MBA programs stated that ranking is a very important factor. This indicates that academic factors (i.e. ranking and reputation in this case) may exert more influence in the enrollment decision than purely financial concerns.

\section{Academic reputation/quality and core competencies of graduate education}

All things being equal, the academic reputation/quality of graduate education has the most pulling effect on the enrollment decision. This is verified by the survey results that the 
academic-related reasons, such as reputation, quality, ranking of university, and program, have very high means (approximately 4 out of 5 in the Likert scale, as shown in Table 5). Many international students also confirmed this during the interviews, as one Chinese student pointed out:

When we choose between two universities, funding is not a big deal. Normally, we choose which university is better, but do not care too much about financial support. Also, because ranking for the university will also impact our future career.

Owing to their cultural background and the educational system, many East-Asian students perceive the reputation, quality, and ranking of the university and program to be very critical. Attending a well-known university with good quality and ranking not only has a "signaling effect," but is also perceived to have a direct correlation with future benefits, such as higher earnings and social status. Therefore, some students may forgo a short-term financial reward (e.g. the level or amount of scholarship or assistantship) in exchange for higher future earnings by attending a top-tier university.

Canadian graduate education is generally perceived as comparable to American graduate education, in terms of the standard, research capability, and quality. How did East-Asian students learn about the research capability and quality of Canadian education, if, as they claimed, it was more difficult to find information about studying in Canada, or that people did not know about Canadian education? There are two plausible explanations. First, the proximity to the United States has some impact on forming this positive perception of Canadian graduate education. There is a perception that there is much academic and/or cultural exchange between the two countries. Second, the high living standard, the diversity and tolerance of Canadian society, and the image of a peaceful country may have contributed to the image of highquality education.

International graduate students came to Canada for academically related reasons, such as the university/program reputation, quality, and ranking. What especially drives the university/graduate program reputation, quality, and to a certain extent, its ranking, is the strength of the research and knowledge creation. These international students often mentioned the faculty and their research topics as important factors influencing their choice of a Canadian graduate school.

At the graduate level, reputation and quality can hardly be manipulated by regular marketing hype. At the "search/selection/application" stage, some international students looked for books and other academic publications written by university faculty members, and contacted the authors directly to gather information about where they should apply. During the application process, it was the one-on-one interaction and contact with the faculty and staff that pulled international students closer to the enrollment decision. In essence, research, creation of knowledge, and publication are at the core of a high quality of graduate education, and without these elements, a graduate program and a university will not be 
able to attain a great reputation and be considered high quality.

As Figure 2 illustrates, the innermost circle-Academic Pulling Factors-is the magnet for attracting international graduate students to Canada. This is an argument for strengthening graduate education by investing in research, and by attracting and encouraging "the best and brightest" to pursue graduate education and to conduct research and create knowledge. However, it is important to note that the benefit of strengthening graduate education is not mainly about attracting international students. There are other benefits more centrally associated with a strengthened graduate education system. First, investing in research and technology has a direct correlation to a country's productivity and prosperity (Task Force on Competitiveness Productivity and Economic Progress Ontario, 2003), as a prosperous economy depends on a highly educated work force and a strong research capability, which also helps attract the "best and brightest" from elsewhere who contribute further to the creation of knowledge, the betterment of society, and even to improving international relations. International graduate students, who belong to the "creative class" (Florida, 2002) and are highly mobile, will choose a destination that promises prosperity, creativity, and innovation for their study and future work. It is in the national interest to attract the "best and brightest" international students as a complement for their domestic counterparts. Therefore, strengthening core competencies by investing in graduate education and research is crucial to the future of an education-exporting country and institution. Secondly, strengthening graduate education will result in enhancing the overall quality of education, and the spillover effect will influence international students at all levels in choosing a host country and host institution. This helps to build "country loyalty" and "brand awareness." In fact, investing in research and ensuring quality of graduate education are the most important ingredients in building “country loyalty." This extends to direct investment in international graduate students, via financial aid that supports the enrollment decision. However, it is important to note that financial aid by itself will not be enough to induce enrollment decisions, as the core competencies-reputation, quality, ranking, and research capabilities-play far more important roles in attracting students. Therefore, effectiveness in recruiting international graduate students in research programs requires both strengthening core competencies and also providing competitive financial support.

\section{Visa and Immigration}

The research findings show the importance of visa and immigration policy on the choice of a host country for study and possible immigration, as many Chinese students reported that they chose Canada as a host country because of "the ease and speed of the visa process" and "the possibility of applying for immigrant status." Thirtysix percent of the survey respondents ranked "the possibility of applying for immigrant status" with high importance (4 and 5 in the Likert Scale) in choosing Canada as a host country. In addition, the interviews 
revealed that Chinese students rated the ease of visa processing as an important factor due to their experience with the student visa process in the United States. They expressed that it was extremely difficult to obtain a US student visa after September 11, 2001. It was "the ease" of obtaining Canadian student authorization rather than "the speed" that was important to these Chinese graduate students. There are two reasons why the speed of visa processing is relatively unimportant. First, a graduate student would typically make an enrollment decision before applying for a visa. Unlike the search/selection/application process of an institution, where international students consider multiple countries and multiple institutions simultaneously to inquire about and to make applications, the visa application is performed sequentially. Throughout the interviews, no students reported that they made multiple visa applications to different countries simultaneously. Some Chinese students reported that they applied to the United States for a student visa, and only after they were rejected did they apply for Canadian student authorization. Secondly, when a graduate student makes a decision to study in a certain host country and institution, he/she considers various factors, such as reputation, quality, ranking, scholarships, tuition fees, learning environment, etc. It is doubtful that a graduate student with a good academic background and with a particular field of study or research in mind would easily be swayed away by the speed of visa process of another lesser-desired country. The key factor is the ability to obtain a student visa from the host country. If too many students find that it is extremely difficult to obtain a student visa from a particular country, then they will start to find an alternative country, as in the case of the United States. The speed of the visa process is less relevant to the choice of a host country for this particular group of students.

This research also explores the relationship among education, immigration, and the mobility of the overseas graduate students. International students perceived that with a Canadian graduate education, they would be highly mobile, and many stated that they could stay in Canada, go to the United States, go to Europe, or return to their home country after completing their studies. By reviewing the international students' future plans, the research findings shed some light on the relationship among education, immigration, and mobility. Twentyeight percent of the respondents agreed that they would like to stay in Canada permanently, and 47 percent of the respondents agreed that they would like to stay in Canada for a short period of time. Thirty-six percent of the respondents reported that they would like to go to another country, which indicates the existence of pull factors from other countries, and a relatively weak loyalty for these students to Canada.

In short, there is a causal relationship between immigration and choosing a host country. As seen in Canada's case, more than one-third of these students came to Canada with the possibility of immigrating to Canada in mind. This acts in Canada's favor in attracting and retaining highly 
talented workers from around the world, and Canada should be able to continue to attract this group of people as potential immigrants. Owing to the fact that these are international graduate students, who can be categorized as highly skilled workers in the world market, they are highly mobile and their future plans are not fixed. The economics of overseas graduate education is important for them, and they will likely choose a path that generates a high return on their investment; in other words, they will go to a place where they can have a satisfying career experience and a high monetary return.

\section{Recruitment of international graduate students}

One of the objectives of marketing higher education to international students is increasing the general awareness of educational services of a particular host country, while one of the objectives of the internationalization of education, in the context of international graduate students, is on enhancing university and program-specific exchanges, learning and research collaboration, and awareness. Recruitment, on the other hand, is an effort made with the objective of enrolling students. Recruitment of international graduate students takes more than internationalization and marketing efforts.

As discussed previously, financial aid is the second most important factor following the importance of university reputation and quality. Many international graduate students have to give up the opportunity to study abroad, when they prove unable to secure financial aid from the university. In such a case, financial aid is a pulling mechanism for enrolling students. However, it is important to note that financial aid by itself will not be enough to induce enrollment decisions, when students have more than one choice. To compete for top students, universities need to use financial aid and scholarships as inducements to lure these potential great researchers to their institutions. Therefore, to effectively recruit top international graduate students in research programs, the host country and host institutions must have a balanced package, that is product and promotion/price; in other words, they need to invest in graduate education and research, including both capital and human assets, as well as providing competitive financial aid packages to research-oriented graduate students.

As for the recruitment of graduate students in the professional programs, improved ranking of the program or university, where applicable, is a key element in marketing these programs and increasing the program profile and awareness. Since international students pay particular attention to program and university rankings, efforts made to improve graduate programs and their rankings are most critical. Specifically, each institution has to decide which strengths to highlight and build upon, and which differentiation strategies they want to pursue in order to attract their target students.

\section{Recommendations}

The graduate education market has been seen as "fragmented" rather than "segmented" (Hesketh and Knight, 1999); however, the research findings 
show that graduate education can indeed be "segmented" by the nature of the program of studies, that is, research programs versus professional programs. The marketing of graduate education to attract international graduate students can utilize the concept of "market segmentation"utilizing internationalization approaches to reach research-oriented students and marketing approaches to reach students in professional programs. To summarize the above discussion, three recommendations are made to advance the goal of an education-exporting country and its higher education institutions to attract and recruit international graduate students. The first recommendation is to strengthen core competencies by investing in research and ensuring a high quality of graduate education. The second recommendation is to devote efforts and resources to the internationalization of higher education, especially graduate education and research, and to initiatives and activities that are more appropriately conducted in a decentralized manner at the program level. The third recommendation is to craft a national marketing strategy that raises the profile of the host country while promoting its graduate education. The overall marketing efforts would be better carried out in a centralized manner to ensure the effective creation of a particular brand and image.

\section{Conclusion}

This research, the first study focusing on both the process and the factors in international graduate students' study abroad decisions, offers some useful insights into why East Asian students choose Canadian graduate schools. It reveals that international students are attracted by strong pulling factors related to the perceived high quality of Canadian graduate programs at a competitive cost and the diverse, multicultural, and tolerant Canadian environment. It confirms the importance for East Asian graduate students of Canada's reputation for tolerance and diversity-consistent with Florida's claim about the importance of the "creative class" in attracting others like themselves-and for public safety. It finds that many students, especially from China, choose Canada because of their difficulties in obtaining a visa in the United Statesa strong negative pushing factor from the United States and also a strong pulling factor for Canada, which benefits from its geographic proximity to the United States. It becomes clear that push-pull forces extend beyond home and host countries-the geopolitical dynamics of home, host, and third countries play a critical role in choosing a host country.

The research also offers a college choice model of the decision process undertaken by international graduate students and shows a three-stage process, guided first by the focus of the program (i.e. research-oriented versus professional programs), followed by other factors-country, institution, and city-that interplay simultaneously rather than in sequence at the later two stages (i.e. search/ selection/application and choice). The activity approach to the internationalization of higher education plays a critical role in guiding research students' decision-making process, and marketing efforts and tactics, such as 
MBA Tours and/or reputational rankings, play a key role in influencing professional students' decision-making process. Internationalization and marketing act as a set of influential factors in pulling these students to Canadian graduate schools.

In analyzing the key influencing factors and the dynamics among these factors, the quality of graduate education and research capability outweigh the importance of financial/ economic factors in making the enrollment decision. From this Canadian study, three recommendations are made for education-exporting countries and institutions to forward their respective goals in competing for and attracting the "best and brightest" international graduate students. It is hoped that this study will generate further discussion and research in this area.

\section{Summary Statement}

International graduate students are a unique group of international students who often do not share common characteristics with undergraduate international students in terms of background (both social-economic and academic), factors influencing their choice of a host country and a host institution, and the decision-making process. The college choice literature gives little consideration to their unique characteristics and in fact typically groups them with other graduate students or with undergraduate international students. However, graduate students themselves can be categorized into two subgroups-research graduate students and professional graduate students. This leads to the concept of market segmentation that helps determine the applicability of internationalization and/or marketing of higher education to each group of students. Research findings show that activities related to the internationalization of higher education play a critical role in influencing the research-oriented students' choice of a host country and a host institution, while marketing activities have a direct impact on students' choice in professional programs. To successfully attract top international graduate students, a higher education institution needs to have a balanced package-program excellence backed by research capability, promotion through competitive scholarships and other forms of financial aid, international collaborations and exchanges, a strong reputation, and a high-perceived value for the education.

\section{Notes}

${ }^{1}$ Parts of this article are based on the following two articles: 'Attracting East Asian students to Canadian graduate schools,' The Canadian Journal of Higher Education, 36, 2, pp. 77-105; 'Choosing Canadian graduate schools from afar: East Asian students' perspectives,' Higher Education, 54, 5, pp. 759-780.

${ }^{2}$ The statements made by the interviewees were largely quoted verbatim, with only minor modifications made in the interest of clarity.

\footnotetext{
References

Agarwal, V.B. and Winkler, D.R. (1985), "Foreign demand for United States higher education: A study of developing countries in the eastern hemisphere," Economic Development and Cultural Change, 33, 3, pp. 623-644.

Altbach, P.G. and Lulat, Y.G.-M. (1985),

"International students in comparative perspective: Toward a political economy of
} 
international study," in J.D. Smart (ed.), Higher Education: Handbook of Theory and Research, Vol. 1, Agathon Press, New York, NY, pp. 439-494.

Altekar, A.S. (1965), Education in Ancient India, Nand Kishore, Varanasi, India.

Arum, S. and Van de Water, J. (1992), "The need for a definition of international education in US universities," in C. Klasek (ed.), Bridges to the Future: Strategies for Internationalizing Higher Education, Association of International Education Administrators, Carbondale, IL.

Austin, M. (1988), Asian Electrical and Computer Engineers at a California University: Why Are They Here? Why Might They Stay?, University of California, Santa Barbara, CA, USA.

Bartlett, K. and Kane, M. (2002), The National Report on International Students in Canada 2000/01, The Canadian Bureau for International Education, Ottawa, ON.

Beerkens, E. and Derwende, M. (2007), "The paradox in international cooperation: Institutionally embedded universities in a global environment," Higher Education, 53, 1, pp. 61-79.

Binsardi, A. and Ekwulugo, F. (2003), "International marketing of British education: Research on the students' perception and the UK market penetration," Marketing Intelligence \& Planning, 21, 5, pp. 318-327.

Brooker, G. and Noble, M. (1985), “The marketing of higher education," College and University, 60, 3, pp. 191-200.

Callan, H. (1998), "Internationalization in Europe," in P. Scott (ed.), The Globalization of Higher Education, Society for Research into Higher Education \& Open University Press, Philadelphia, PA, pp. 44-57.

Canadian Association for Graduate Studies (2005), 35th Statistical Report 1994-2003, Canadian Association for Graduate Studies, Ottawa.

Citizenship and Immigration Canada (2003, January), "Foreign students in Canada 1980-2001,” from http://cicnet.ci.ca/english/srr/ research/foreign-students/students-toc.html.

Citizenship and Immigration Canada (2006), "Foreign students Overview (1996-2005)," from http://www.cic.gc.ca/english/resources/statistics/ monitor/pdf/issue-15e.pdf.

College Entrance Examination Board (1976), A Role for Marketing in College Admissions, College Entrance Examination Board, New York, NY.

Cummings, W.K. (1984), "Going overseas for higher education: The Asian experience," Comparative Education Review, 28, 2, pp. 241-257.

Cummings, W.K. and So, W.-C. (1985), “The preference of Asian overseas students for the
United States: An examination of the context," Higher Education, 14, 4, pp. 403-423.

Davis, T.M. (2000), Open Doors: Report on International Educational Exchange, Institute of International Education, New York, NY.

Dedijer, S. (1968), “"Early” migration,” in W. Adams (ed.), The Brain Drain, Macmillan, New York, NY.

de Wit, H. (2002), Internationalization of Higher Education in the United States of America and Europe: A Historical, Comparative, and Conceptual Analysis, Greenwood Press, Westport, CT.

Enders, J. (2004), "Higher education, internationalisation, and the nation-state: Recent developments and challenges to governance theory," Higher Education, 47, 3, pp. 361-382.

Florida, R. (2002), The Rise of the Creative Class and How its Transforming Work, Leisure, Community and Everyday Life, Basic Books, New York, NY.

Gagnon, J.P. and Cocolas, G.H. (1988), "Understanding what motivates someone to pursue pharmacy graduate education," American Journal of Pharmaceutical Education, 52, 1, pp. 10-15.

Gertler, M.S., Florida, R., Gates, G. and Vinodrai, T. (2002), "Competing on creativity: Placing Ontario's cities in North American context," [Electronic Version] from http://www.urban. org/UploadedPDF/410889_Competing_on_ Creativity.pdf.

Glaser, W.A. (1978), The Brain Drain: Emigration and Return: Findings of a Unitary Multinational Comparative Survey of Professional Personnel of Developing Countries Who Study Abroad, Pergamon Press, Oxford, New York.

Government of Canada (2002, September 30), "The Canada we want-Speech from the throne to open the second session of the thirty-seven parliament of Canada," Retrieved June 2, 2003, from http://www.pco-bcp.gc.ca/sft-ddt/sft.htm.

Harari, M. (1977), "Internationalization of higher education," in A.S. Knowles (ed.), The International Encyclopedia of Higher Education, Jossey-Bass, San Francisco, CA.

Harari, M. (1989), Internationalization of Higher Education: Effecting Institutional Change in the Curriculum and Campus, Center for International Education, California State University, Long Beach, CA.

Harman, G. (2002), "Australia as a major higher education exporter," Paper presented at the Consortium of Higher Education Research (CHER), available from http://www.iff.ac.at/ hofo/CHER_2002/pdf/ch02harm.pdf.

Harman, G. (2005), “Internationalization of Australian higher education: A critical review of literature and research," in P. Ninnes \& 
M. Hellstén (eds.), Internationalizing Higher Education: Critical Explorations of Pedagogy and Policy, Vol. 16, Springer Netherlands, Hong Kong, pp. 119-140.

Hemsley-Brown, J. and Oplatka, I. (2006), "Universities in a competitive global marketplace: A systematic review of the literature on higher education marketing," International Journal of Public Sector Management, 19, 4, pp. 316-338.

Hesketh, A.J. and Knight, P.T. (1999), "Postgraduates' choice of programme: Helping universities to market and postgraduates to choose," Studies in Higher Education, 24, 2, pp. 151-163.

Hess, G. (1982), Freshmen and Sophomores Abroad: Community Colleges and Overseas Academic Programs, Teachers College Press, New York, NY.

Hossler, D.R. and Gallagher, K.S. (1987), "Studying student college choice: A three-phase model and the implications for policymakers," College and University, 62, 3, pp. 207-212.

Knight, J. (1999), "Internationalisation of higher education," in H. de Wit (ed.) Quality and Internationalisation in Higher Education, Vol. 1999, OECD, Paris, pp. 13-28.

Kotler, P. and Fox, K.F.A. (1985), Strategic Marketing for Educational Institutions, Prentice-Hall, Englewood Cliffs, NJ.

Krampf, R.F. and Heinlein, A.C. (1981) "Developing marketing strategies and tactics in higher education through target market research," Decision Sciences, 12, 2, pp. 175-192.

Lee, E.S. (1966), "A theory of migration," Demography, 3, 1, pp. 47-57.

Lee, K.H. and Tan, J.P. (1984), "The international flow of third level lesser developed country students to developed countries: Determinants and implications," Higher Education, 13, 6, pp. 687-707.

Mazzarol, T. and Hosie, P. (1996), "Exporting Australian higher education: Future strategies in a maturing market," Quality Assurance in Education, 4, 1, pp. 37-50.

Mazzarol, T. and Soutar, G. (2002a), The Global Market for Higher Education: Sustainable
Competitive Strategies for the New Millennium, Edward Elgar Publishing, Cheltenham, UK.

Mazzarol, T. and Soutar, G. (2002b), "“Pushpull” factors influencing international student destination choice," The International Journal of Educational Management, 16, 2, pp. 82-90.

Neice, D.C. and Braun, P.H. (1977), Patron for the World, Canadian Bureau for International Education, Ottawa, Ontario.

Olson, C. (1992), "Is your institution user-friendly? Essential elements of successful graduate student recruitment," College and University, 67, 3, pp. 203-214.

Poock, M.C. and Love, P.G. (2001), "Factors influencing the program choice of doctoral students in higher education administration," NASPA Journal, 38, 2, pp. 203-223.

Rao, G.L. (1979), Brain-Drain and Foreign Students: A Study of the Attitudes and Intentions of Foreign Students in Australia, the USA, Canada, and France, University of Queensland Press, St. Lucia.

Schoorman, D. (1999), "The pedagogical implications of diverse conceptualizations of internationalization: A US based case study," Journal of Studies in International Education, 3, 2, pp. 19-46.

Sirowy, L. and Inkeles, A. (1984), "Universitylevel student exchanges: The US role in global perspective," in E.G. Barber (ed.), Foreign Student Flows: Their Significance for American Higher Education, Institute of International Education, Spring Hill Center, Wayzata, Minnesota, pp. 31-85.

Task Force on Competitiveness Productivity and Economic Progress Ontario (2003), Investing for Prosperity-Second Annual Report, Institute for Competitiveness \& Prosperity (Ontario), Toronto.

Webb, M.S. (1993), "Variables influencing graduate business students' college selections," College and University, 68, 1, pp. 38-46.

Zikopoulos, M. and Barber, E.G. (1986), Choosing Schools from Afar. The Selection of Colleges and Universities in the United States by Foreign Students, Institute of International Education, New York, NY.3 